\title{
Interactive comment on "Debris Flow Risk Mapping Based on GIS and Extenics" by Wenbo Xu et al.
}

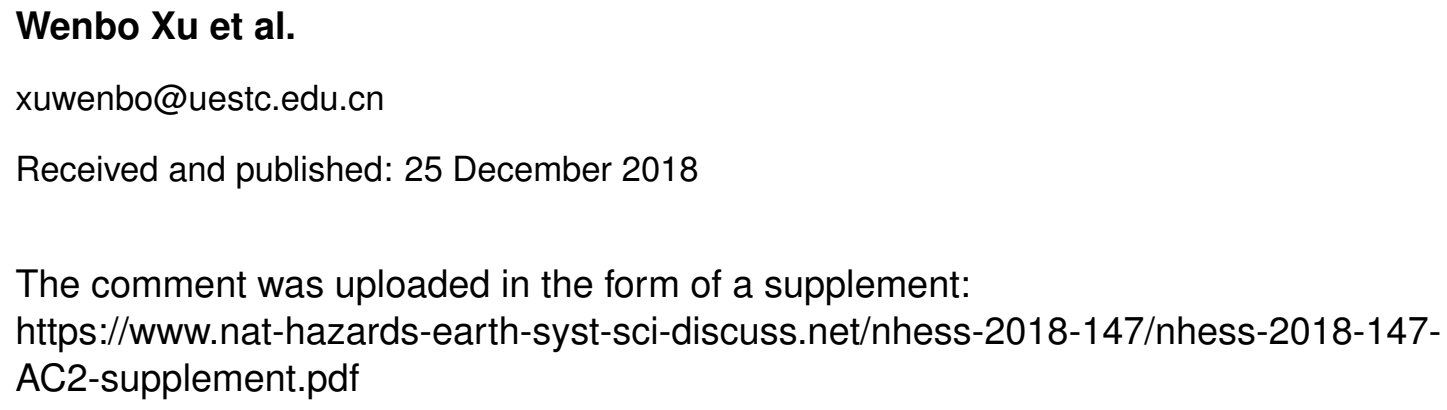

The comment was uploaded in the form of a supplement: https://www.nat-hazards-earth-syst-sci-discuss.net/nhess-2018-147/nhess-2018-147AC2-supplement.pdf

Interactive comment on Nat. Hazards Earth Syst. Sci. Discuss., https://doi.org/10.5194/nhess2018-147, 2018. 